\title{
Child Suppport Grant: A Dangling Carrot In Curriculum Development
}

\author{
Mutendwahothe Walter Lumadi \\ University of South Africa \\ Department of Curriculum \& Instructional Studies \\ Lumadmw@unisa.ac.za
}

Mantsose Jane Sethusha

Doi:10.5901/mjss.2013.v4n14p669

\begin{abstract}
In this article, South Africa's Child Support Grant (CSG), which is a dangling carrot in curriculum development, is critiqued. This study shows that the rate of teenage pregnancy, which is fuelled by the CSG, in high schools is alarmingly high. Teachers allege that girls are lured by the CSG given to mothers to drop out of schools with the intention to babysit. The proliferation of illegitimate children born into poverty engulfs huge swathes of the country and affects the development of the school curriculum. This study was conducted in one of the districts of Limpopo province where ten schools obtained a $0 \%$ pass rate in the National Senior Certificate Examinations in 2011/12. Ninety-nine per cent of the Grade 12 learners in these schools are girls who happened to fail the gateway subjects such as Mathematics and Physical Science. The findings revealed that a decrease in education resulted in an increase in fertility and that the CSG in combination with poverty causes teenagers to drop out of school at a tender age.
\end{abstract}

Keywords: South Africa, child support grant, curriculum development, prostitution, poverty eradication, parental influence

\section{Introduction}

The South African government is addressing the worst poverty in the country through a massive social grant system, which grows in strength on a yearly basis. Social grants increased from 2,5 million recipients in 1998 to 13 million in 2009. Much of this increase was due to the expansion of the Child Support Grant (CSG), which by 2009 reached nine million children under the age of 15 . Some politicians are of the opinion that there is a link between teenage fertility and the deceiving CSG.

The CSG is a government initiative designed to assist primary caregivers who are experiencing financial difficulties. This grant provides primary caregivers, who may be parents or someone legally assigned with the care of a child under the age of 15 , with a monthly stipend intended to assist with childcare-related costs (DSG, 2012). In addition, primary healthcare is free for pregnant women and children under the age of six and the poorest children are exempt from paying school fees, a policy that aims to increase the enrolment and retention of children who would otherwise be destined for a bleak future (Unicef, 2010).

Many teenagers do not perform as expected at school. This naturally is a source of grave concern for both parents and teachers. Moreover, it has been noticed that, in some instances, there is an emotional trauma lurking behind a learner's under performance. Many parents lament the CSG, believing that it affects young girls in the school curriculum as well as the country's economy. It has also been found that termination of pregnancy by young girls has decreased over time and that there is a high uptake of the lucrative CSG among teenagers.

Educational opportunities for children from previously disadvantaged backgrounds improved considerably with the birth of the new democracy. The country prioritised girls' education, resulting in almost as many girls being enrolled in primary school as boys. In secondary schools, too, girls outnumber boys. However, many political parties are of the opinion that, as long as the CSG exists, in the next ten years the increase in the numbers of illiterate mothers and, as a consequence, poverty will be alarming. In addition, even when they are in school, the poor quality of the education offered to these children undermines their ability and desire to learn. Many children experience a broken journey through school, interrupted by irregular attendance, absent teachers, teenage pregnancy and abuse and violence in and around schools. The South African education system is a kind of generalisation that is thought to be well suited to the 
educational needs of most learners. However, it has been realised that many female learners are not able to fit the situation as envisaged by the education system (Demery, 1996).

\section{Literature Review}

This study is partly grounded in Russell and Cutrona's $(1984 ; 1989)$ theory of social support. Social support can be viewed and measured in numerous ways and may be loosely defined as the feeling that one is cared for by and has assistance available from other people and that one is part of a supportive social network. These supportive resources can be emotional (e.g. nurture), tangible (e.g. financial assistance), informational (e.g. advice), or companionship (e.g. sense of belonging). Social support can be measured as the perception that one has assistance available, the actual received assistance, or the degree to which a person is integrated in a social network. Support can come from many sources, such as family, friends, government organisations, co-workers, and so forth. Moreover, social support is important to many people interested in physical health (e.g. mortality) and mental health (e.g. depression).

In general, social support has been linked to many benefits for both physical and mental health, but social support is not always beneficial. Two main models have been proposed to describe the link between social support and health: the buffering hypothesis and the main effects hypothesis. Additionally, several theories and biological pathways for the link between social support and health have been proposed. Gender and cultural differences in social support have also been found.

There are four common functions of social support:

$>$ Emotional support is the offering of empathy, concern, affection, love, trust, acceptance, intimacy, encouragement, or caring. It is the warmth and nurturance provided by sources of social support. Providing emotional support can let the individual know that he or she is valued. It is also sometimes called esteem support or appraisal support. In a school set up, learners who are affected psychologically by family abuse, prostitution and poor academic work would need this type of support.

$>$ Tangible support is the provision of financial assistance, material goods, or services. Also called instrumental support, this form of social support encompasses the concrete, direct ways people assist others. The CSG in the country is a government initiative designed to assist primary caregivers who are experiencing financial difficulties. Further, bursaries from the Department of Education may help learners to achieve worthwhile results.

$>$ Informational support is the provision of advice, guidance, suggestions, or useful information to someone. In this case, it would refer to the classroom situation where teachers impart knowledge of Mathematics and Physical Science, among other subjects, to Grade 12 learners. This type of information has the potential to help both teachers and learners in solving problems. Learners at school should always be guided by teachers in their academic lives.

$>$ Companionship support is the type of support that gives the learner a sense of social belonging. This can be seen as the presence of companions to engage in shared social activities.

\section{Research Methodology}

The approach used in this study is both qualitative and quantitative. Qualitative methods are described as naturalistic and humanistic and therefore true to life, whereas quantitative methods are mainly experimental (Guba \& Lincoln, 1994). However, these two methods represent complementary components of the research process (Leedy \& Ormrod, 2001). These approaches were used to determine the participants' knowledge and information about the CSG and its impact on curriculum development.

\section{Findings and Discussion}

The indicator in table 1 shows the number of children who are accessing the CSG in South Africa, as recorded in the administrative data system of the South African Social Security Agency. 
Table 1: Children Accessing The Csg In South Africa

\begin{tabular}{l|r|r|r|r|r|}
\hline \multicolumn{7}{|c|}{ The number of children receiving the Child Support Grant in South Africa, $\mathbf{2 0 0 5} \mathbf{- 2 0 0 9}$} \\
\hline Province & $\mathbf{2 0 0 5}$ & $\mathbf{2 0 0 6}$ & $\mathbf{2 0 0 7}$ & $\mathbf{2 0 0 8}$ & $\mathbf{2 0 0 9}$ \\
\hline Eastern Cape & $1,078,442$ & $1,413,830$ & $1,497,736$ & $1,491,223$ & $1,605,479$ \\
\hline Free State & 361,318 & 417,076 & 441,397 & 457,169 & 494,433 \\
\hline Gauteng & 723,432 & 862,346 & 926,179 & 969,267 & $1,067,729$ \\
\hline KwaZulu-Natal & $1,338,045$ & $1,746,944$ & $1,963,944$ & $2,128,967$ & $2,344,413$ \\
\hline Limpopo & 990,194 & $1,200,185$ & $1,253,794$ & $1,278,711$ & $1,392,140$ \\
\hline Mpumalanga & 489,663 & 613,008 & 645,565 & 662,316 & 717,075 \\
\hline North West & 465,242 & 604,525 & 613,002 & 637,557 & 682,991 \\
\hline Northern Cape & 101,728 & 121,332 & 175,250 & 184,183 & 209,818 \\
\hline Western Cape & 365,655 & 431,514 & 458,980 & 480,394 & 557,784 \\
\hline South Africa & $\mathbf{5 , 9 1 3 , 7 1 9}$ & $\mathbf{7 , 4 1 0 , 7 6 0}$ & $\mathbf{7 , 9 7 5 , 8 4 7}$ & $\mathbf{8 , 2 8 9 , 7 8 7}$ & $\mathbf{9 , 0 7 1 , 8 6 2}$ \\
\hline CSG amount & $\mathbf{R M 1 8 0}$ & $\mathbf{R M 1 9 0}$ & $\mathbf{R M 2 0 0}$ & $\mathbf{R M 2 2 0}$ & $\mathbf{R M 2 4 0}$ \\
\hline & & & & & \\
\hline
\end{tabular}

\section{Source: Unicef (2010:14)}

\section{First Finding: Rate Of Prostitution}

Child prostitution itself is a criminal activity and serves as a catalyst for further criminal association in other fields. The helpless teenagers are turned into mere pawns by criminal syndicates which lead to a steady deterioration of morals (Phoenix, 2001). Young girls end up flirting with men because they are looking for illegitimate children which will enable them to qualify for CSG.South African school teenagers are lured into prostitution through CSG. Once they are trapped in prostitution it is difficult for them to escape. CSG is misleading girls as young as 13 to be truant at school to sell their bodies for as little as a loaf of bread or a small bottle (300 ml) of Coca-Cola. The CSG is appropriated for make-up and hair styles and expensive clothing to attract pimps. Pimps only target young girls aged 14 to 18 who have a baby so that they can control the girl's visits with the baby based on how much money she earns (Mason, 1994). For most of these children, life with a pimp is better than life at home which cannot compete with the lifestyle afforded through prostitution and association with a pimp. Competition is now stiff among the young girls as to who gets pregnant almost every second year. Fifteen to twenty per cent of girls aged 14 to 16 give birth in each high school annually.

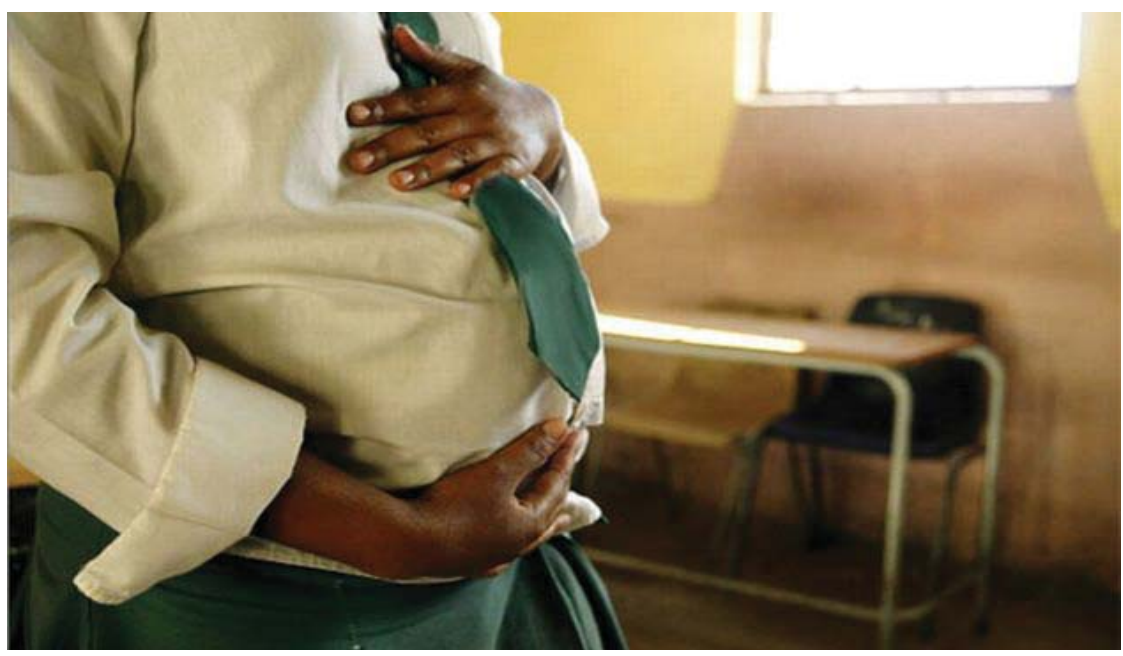


The police, the brothel keepers and pimps share a major part of a prostitute's earnings and the rest that percolates down to the prostitutes is a mere pittance. It is alleged that the police accept the hospitability, money and free use of the girls in brothels. The police help the brothel keeper even by bringing back the ones who have run away (Potterat, 1990).

Traffickers surf the social networking sites, looking for attractive young girls. After identifying a potential victim, they would contact her online using phony identities complimenting her on her looks, asking to get to know her better, sometimes offering her the opportunity to make money as a result of her looks. If the victim expresses interest flattered by the attention, there would be a request for the cell phone number to contact using calls, whatsApp and face book and even make plans to meet for dinner on a weekend. They are even promised bursaries for medicine and engineering jobs over the holidays which would pay them a lot of money. During extracurricular activities, girls are lured into engaging in commercial sex, often with the help of more senior girls showing them the ropes. These girls are sent to an apartment complex with instructions to knock on doors looking for potential customers. They are driven to hotels in limousines for pre-arranged meetings or taken to a brothel where paying customers are allowed to have sex with them.

A class teacher for Grade 12 in school X registered his concern by mentioning the following;

"Most teenagers in my class do not attend classes for five days in a week. The reality is that they attend 3-4 days in a week. Last week I had 6 girls who missed all the Mathematics and Physical Science examinations".

The above quote is corroborated by irresponsible Grade 12 female learners from various schools when they indicated;

"Last year I wrote a Mathematics paper 1 and unfortunately missed paper 2 because I had to deliver on the day it was written". A learner at another school also shared a similar experience. "I failed to sit for a Physical Science paper because I was not prepared. When I try to read I fall asleep and I am always tired. Even when I am in class I get bored because I do not concentrate."

It is evident from the above discussions that female learners from this district are irresponsible, hence they get the $0 \%$ pass rate in Mathematics and Physical Science. A learner cannot pass the examination if she missed some or all examination papers. Apart from that, one assume that they did not bother themselves by thorough preparations. A dedicated learner would always aim to pass the examinations with flying colours and not just borderline cases. It is incumbent upon them to make sure that they change their negative attitude. These teenagers cannot prioritise. Having a baby is of paramount importance in their lives unlike passing the examinations. A baby will earn the CSG which they will use as they please. According to a report from the Department of Social Development (2012) about 45276 learners in South Africa fell pregnant in 2009. However, pregnancy has also increased among girls in grade 3 to 5 . In 2009 about 109 learners in grade 3 fell pregnant. KwaZulu-Natal recorded 12954 pregnancies, Limpopo 10 323, Eastern Cape 8420 and Western Cape 1983 . Most of the learners were in grade 12. The figure is also expected to be higher in KwaZulu-Natal schools once reports for 2011/12 have been compiled. A total of 12971 learners had fallen pregnant in 2010 in the province, according to education officials and the figure for 2011 could be about 13000 . In June, the Ministerial report confirmed that the department was already aware of 465 schoolgirl pregnancies (see table 2 below for statistics of teenagers who fell pregnant in 2011-12).

Table 2: Statistics Of Teenageragers Who Fell Pregnant In 2011-2012

\begin{tabular}{|l|l|l|}
\hline PROVINCE & NO OF PREGNANT TEENAGERS & TOTAL \\
\hline Eastern Cape & 8420 & \\
\hline Free State & 8557 & \\
\hline Gauteng & 13654 & \\
\hline Limpopo & 10323 & \\
\hline KwaZulu-Natal & 12954 & \\
\hline Mpumalanga & 8652 & \\
\hline Northern Cape & 6102 & \\
\hline North West & 7532 & 82177 \\
\hline Western Cape & 5983 & \\
\hline
\end{tabular}

Source: Sowetan (2012:12) 


\section{Second Finding: Poverty And Education}

Although the CSG is meant to eradicate poverty in families, it is unfortunately perpetuating poverty because every teenager wants to bear children as if they are vying for a Nobel prize. This is a bleak circumstance characterising in girls' lives. The high cost of education in developed and underdeveloped countries is the biggest deterrent to families educating their children and in particular girls (Colclough, 1994). African women are at the heart of most African societies. Regardless of whether they are working or not, mothers are very influential people in the lives of their girls at home. Empowering girls with education is one of the most important investments that any country can make in its own future. Education has a profound effect on girls' and women's ability to claim other rights and achieve status in society, such as economic independence and political representation. It goes without saying that girls from poor backgrounds are vulnerable to abuse, which is viewed as ordeals and experiences that no girl should under no circumstance encounter in her life.

South Africa's high levels of poverty continue to deny thousands of children access to quality education. Around $27 \%$ of public schools do not have running water, $78 \%$ are without libraries and $78 \%$ do not have computers (Unicef, 2010 \& Baden, 1997). Poverty has lent impetus to the sex trade and despite the threat of HIV and Aids, to some it is the only key to a brighter future which is currently bleak. Youth unemployment in the country is thought to top $84 \%$ and many cannot afford to pay for school fees, transport costs, food and medical bills.

Eighty-five per cent of Mathematics teachers confirmed that it is poverty that makes it difficult for teenagers to excel in school work because poverty creates chronic stress that impairs attention and concentration. When girls are focused on meeting basic needs and dealing with unstable home lives, schoolwork is often not a priority because it does not offer a grant (Appleton, 1997). Girls living in vicious poverty also have less access to parents who can provide assistance with gateway subjects such as Mathematics and Physical Science. Girls from such a poor background are vulnerable because their lives are filled with emotional instability. Their parents may often force their daughters to have boy friends at an early age, which disrupts the social interactions of the teenagers both in their schools and in the community at large. They struggle to understand how to display healthy and appropriate emotional responses to everyday situations, which makes it difficult to create strong friendships with peers.

Teachers complain about teenagers who dodge Physical Science lessons to spend time with "sugar daddies" who buy them airtime below R20.00 (U\$2-00) and cellular phones. In the long run, they are ultimately impregnated. Bunking class is a very familiar case in South African schools. For the most part, learners run away from schools because of reasons like expulsion, suspension, boredom and abuse at home. As they begin to abandon knowledge and education for something else, they have a very high probability of getting in the prostitution trade (King, 1993).

The illegitimate child becomes a passport for entrance to the promised land of CSG. The amount changes every year, but in 2011 the CSG was R260 a month. A mother can get this grant for up to five children. Currently a mother can only get the grant for children younger than 18 years old. A Grade 12 learner from school Y remarked as follows:

I am not shy to tell you that I am a commercial sex worker. I found myself in this trap when I lost my parents in a car accident. As an orphan there was no bread winner in the family of four kids. My uncle offered to take me to school. Little did I know that I was running from the frying pan into the fire. He took me to his brothel in Polokwane. My dreams for furthering studies were shattered. I then resorted to selling my body since I completed my Grade 8 three years ago in one of the schools around Thohoyandou. My going rate wavers between $R 150.00$ and R200.00 per session. I manage to see five to six men in a daily basis.

This grade 12 girl is prone to abuse of all forms, and very often confined to households in which she is virtually a slave. As long as CSG is not terminated, the country will continue having street children born from schools. Street children and children of some ethnic minorities are children who merit special care. For them, the provision of non-academic support and security is vital in order to contribute to their total wellbeing and success in life. Exploitation of girls through the grant will remain the key challenge to success in life.

Poverty is strongly linked to teenage pregnancy. In Africa, the continent with the highest percentage of teenagers living in poverty also has the highest proportion of births, to unwed teenage mothers. Giving birth while still a teenager at school makes it extremely difficult for a young mother to break the cycle of poverty and give her child a better life. Teenage pregnancy almost always results in girls halting their education. Girls' labour is used to substitute for mothers' in work such as caring for siblings, fetching wood and water, caring for animals and pounding grain. The loss of girls' labour 
during school hours thus has an impact on women's ability to raise household income either through food production or wage labour (Rose,Yoseph, Berrihum \& Nuresu,1997).

In South Africa, CSG compels girls at the age of eighteen to end up in early marriages. These girls are more likely to drop out of school because of this CSG and the rate of divorce within the first two years of marriage is overwhelming.

\section{Third Finding: Negative Parental Influence}

Russell and Cutrona (1984) state that curriculum developers are of the opinion that teacher quality is the number one statistical correlate of measurable learner learning. Parental socioeconomic status, as measured in a variety of different ways, is far and away the biggest correlate of learner achievement. Teacher quality is the most important in-school factor, but out-of-school factors still have a bigger correlation (Russell \& Cutrona, 1989). It is believed that some parents are behind the shameful acts of encouraging their children to sleep around with men who will be able to take care of their babies, teenage mothers and the in-laws. A person who grows up in a household headed by a single mother who did not complete high school is going to be at a significant educational disadvantage.

You are now 15 years old. All girls of your age have kids. What are you waiting for? Are you bewitched for books? When will you bring a child to this family? I will look after my grandchild whist you are at school. It is long overdue. I am an unemployed single mother and cannot afford your lifestyle. Get someone to look after you. The government gives a monthly stipend to all children younger than 18 years. Some of my friends buy groceries with money of their grandchildren. It is high time that you strike the iron whilst it is still hot. Otherwise I will have to organize someone special to come and spend a night with you on a daily basis. If you do not heed my call I will burn your books or be compelled to deregister you.

This single mother is putting her daughter under a dangerous cloud in her own home. As long as the abuse is continued and prolonged, the 15 year old girl is able to build more reason to succumb to the pressure. As she sees her mother neglecting her, it seems like hope to alleviate poverty is nowhere to find. She discourages her daughter from furthering her studies. She is lured by CSG which is temporary. In her mind she wants to prove to her friends that her daughter is not cursed by gods, she can also conceive. Once she gives birth, there will be food on the table from the government's monthly stipend. To aggravate things, this mother is disrespectful to her daughter hence she threatens to burn her books or deregister her from school. This mounted pressure makes the daughter feel guilty. She is no longer sure as to whether she is barren or not. If so, the stigma attached to it will worsen the matter. For anyone who is a minor in the eyes of the law, this kind of traumatic experience is impossible to bear and the only way to get out of it is to get a boyfriend who will enable her to bear a child. If she does not do that, she may end up with an elderly person she does not like. One wonders what will happen after give birth to the first child.

Early pregnancy is a factor reducing female education. In many countries the legal minimum age at marriage, and the actual age, are lower for females than for males. Early marriage therefore probably acts as a deterrent to female education more than male (Appleton, 1997). Pregnancy also disrupts girls' schooling, and in many countries unlike in South Africa where learners have rights, girls are automatically expelled if pregnant. The early marriage of girls links to poverty as poor households may push daughters to marry for economic reasons - to save on their upkeep, or to obtain bride wealth. Girls from poor households may also be more likely to engage in sexual survival strategies to secure support for their schooling, risking pregnancy and the curtailment of the education.

Although schools are encouraged to draw up detailed policy for assessment, involving parents, this daughter cannot get assistance from her mother. This policy should have sanctions for learners who fail to do homework. If the learner does not do homework that has been set in these circumstances, the school could argue that the learner is in breach of school policy and rules and could take steps to discipline them. From the look of things, this parent cannot assist her daughter in her homework or any school activity requiring parental support. A parent should be concerned that his child is being given too much or too little homework. If the school has a homework policy, this irresponsible parent will not check to find out how much homework is set for Mathematics and Physical Science and how much time the school expects a learner to spend on it. It is devastating to note that many learners drop out of schools because of parental pressure. Some of the parents preclude their children from attending school on daily basis and writing examinations. When they are invited to parents meetings, they do not attend and do not bother to send apologies. They force their children to have affairs with elderly people because they have money. This type of affair will result in pregnancies which will bring the offspring. Once there is an offspring, the CSG will look after the family. 
It is imperative to note that teenagers are the most defenceless and vulnerable members of any society (Potterat, 1990). They are easy targets for any kind of malicious and exploitative objective from parents. While most girls from developing countries are well educated by academic institutions, there are many unfortunate African girls who have not even set foot in a school. However; the risk factor involved in here is not the absence of access to education but the lack of parental support and interest in it. Teenagers that lack parental support in school activities, like the 15 year old girl, are very prone to prostitution. By being away from an institution that provides them with the tools to combat negative aspects of society, they become very misguided and imprudent. As a result, they may likely be approached by pimps and traffickers, who think they have a very precious commodity at hand.

With the rates of homeless children increasing, the role of teachers is also increasing. Teachers at schools work hard to try and lighten the load of the hard life style that learners face by offering counselling, clothing, and other resources (Demery, 1996). Although teachers are challenged daily to inspire learners to strive higher; this behaviour places teachers into a precarious position that forces them to have to deal with other aspects of learner's lives, outside of academics, a role that most teachers cannot handle.

\section{Concluding Remarks}

The greatest challenge facing learners is dealing with the increased freedom which learners experience when they are away from home. Choices are presented regarding friends, the use of time, personal habits, social activities, and even whether or not to attend class or do assignments. These choices are accompanied by consequences. Although friends, parents, and churches may advise, the choices and consequences are ultimately the responsibility of the learner. Practice of child prostitution is economically unsound, psychologically disastrous, and morally dangerous and harmful on children. One can hardly imagine the extreme trauma that a child under goes. Child prostitutes become ready recruits for flesh trade for they are rendered unfit for any other trade not being educated. Without sophisticated shelter and comprehensive social services combined with adequate living quarters, prostitutes will return to the streets because underfunded and underdeveloped shelter cannot compete with the promises of a pimp.

\section{References}

Appleton S 1997. Leaping into the ark: some reflections on free primary education in Uganda. Centre for the Study of African Economies: University of Oxford.

Baden S 1997. Women's special situation, population issues and gender perspectives in Mozambique and the integration of these concerns into skills, training and employment promotion. Report for the ILO. Geneva; International Labour Organization.

Colclough C 1994. Under-enrolment and low quality in African primary schooling: towards a gender-sensitive solution. IDS Working Paper 7. Brighton: IDS.

Demery L 1996. Gender and public social spending: disaggregating benefit incidence. Washington D.C.., World Bank Poverty and Social Policy Department.

Department of Social Development (DSD). 2012. Grant for caring for young child. Government Printer: Pretoria.

Guba E, Lincoln Y 1994. Competing paradigms in qualitative research. In N. Denzin \& Y. Lincoln (Eds.), Handbook of qualitative research (pp.105-117). Thousand Oaks, CA: Sage.

King EM, Hill A 1993. Women's education in developing countries. Baltimore, ML: John Hopkins University Press.

Leedy PD, Ormrod JE 2001. Practical research: Planning and design (7th ed.). Upper Saddle River, NJ: Merrill/Prentice Hall.

Mason AD 1994. Schooling decisions, basic education, and the poor in rural Java, PhD. Thesis. Food Research Institute: Stanford University

Phoenix J 2001. Making sense of prostitution. Basingstoke, UK: Palgrave

Potterat JJ 1990. Estimating the prevalence and career longevity of prostitute women. Journal of Sex Research 27: 233-243.

Rose P, Yoseph G, Berrihun G, Nuresu T 1997. Gender and primary schooling in Ethiopia. IDS Research Report 31, Brighton: IDS.

Russell D, Cutrona CE 1984. Social and emotional loneliness: an examination of Weiss's typology of loneliness. Journal of Personality and Social Psychology, 46(4): 1313-1321.

Russell D, Cutrona CE 1989. The Social Provisions Scale: a multidimensional measure of perceived social support. Unpublished manuscript.

Sowetan. 2012. Teenage pregnancy in schools. Johannesburg: South Africa.

Unicef. 2010. Women and children in South Africa: South African Development Indicators. Pretoria. 
